Foraminiferal Study of the Magdalen Shallows, Gulf of St. Lawrence*

G. VILKS

Atlantic Oceanographic Laboratory, Bedford Institute, Dartmouth, N. S.

\title{
Introduction
}

This is a preliminary report on studies of Foraminifera taken from bottom sediments in the Magdalen Shallows (see Fig. 1). The purpose of the study is to compare Foraminifera found in the Gulf of St. Lawrence, the Arctic, and North Atlantic waters. The field program was carried out during late August of 1963 in cooperation with the Fisheries Research Board of Canada. Samples of bottom sediment were taken aboard CNAV "Sackville", Cruise S-75, with a modified Van Veen bottom grabber and processed at the Bedford Institute, using the conventional methods (Vilks, 1964).

Grateful acknowledgement is extended to Dr. D. H. Loring of the Fisheries Research Board of Canada for cooperation and help given during the sampling, to Dr. G. A. Bartlett for much helpful advice during the study, and to N. W. Fowler for assistance in the field and laboratory.

Previous Work

Literature used in the present study consists primarily of publications discussing Foraminifera from the Arctic (Loeblich and Tappan, 1953, Cushman, 1948, Phleger, 1952) and the Gulf of Maine (Parker, 1952a, b). Studies of Foraminifera in the Gulf of St. Lawrence are few. Dawson (1870) gave a faunal list and a few illustrations of Foraminifera from the Gaspe region. Sproule (1961) discussed distribution of benthonic Foraminifera taken from the Magdalen Shallows and the Laurentian Channel. His report includes a faunal list but lacks illustrations of species. Bartlett $(1965,1966)$ described nearshore Foraminifera from the Miramichi Estuary and Tracadie Bay and Schafer (1967) reported on sampling problems of nearshore sediments.

\section{Physical Environment}

Bottom conditions on the Magdalen Shallows are characterized by low water temperatures, coarse sediment and relatively featureless submarine topography. According to Lauzier (1957), the waters of the Gulf of St. Lawrence are stratified in layers that have different temperature and salinity characteristics. Mainly three layers are recognized: the warm surface, the cold intermediate and the warmer layer below the intermediate. Over the Magdalen Shallows only two layers are present which vary in time and space. During the late summer the temperature of the surface layer is relatively high and may reach $16-17^{\circ} \mathrm{C}$, but decreases sharply below a depth of approximately 10 metres. At approximately 50 metres it is $0.0^{\circ} \mathrm{C}$ both in early spring and late summer. The sharp thermocline loses its identity in the autumn as the surface layer becomes thicker and cooler. In winter the whole area over the Magdalen Shallows is uniformly cold.

The bottom temperature in the Gulf of St. Lawrence is, therefore, a function of bathymetry and the time of year. The range of depth over the central part of the Magdalen Shallows is between 40 and 90 metres and is within the cold intermediate layer with small seasonal changes in temperature taking place. The shallower nearshore localities are within, or close to, the surface layer and are exposed to drastic changes in seasonal temperature. The nearshore localities are also exposed to lower salinities with respect to the central part of the Shallows. During the cruise, salinities at the bottom were recorded from 30.784 to 32.383 parts per thousand with the lesser values at the nearshore stations.

The bottom sediment collected consists chiefly of reddish-brown sand. In addition to the sand a number of samples contain pebbles and cobbles of red sandstone. In the vicinity of the Magdalen Islands the bottom is dominated by clean and well-sorted sand, but in the vicinity of Prince Edward Island the sediment is less well-sorted and contains mud in addition to pebbles mixed with the sand.

\section{Discussion of Species}

The relatively small foraminiferal population of the Magdalen Shallows is dominated by arenaceous species. (See Table I). In this report the more abundant species are treated in some 


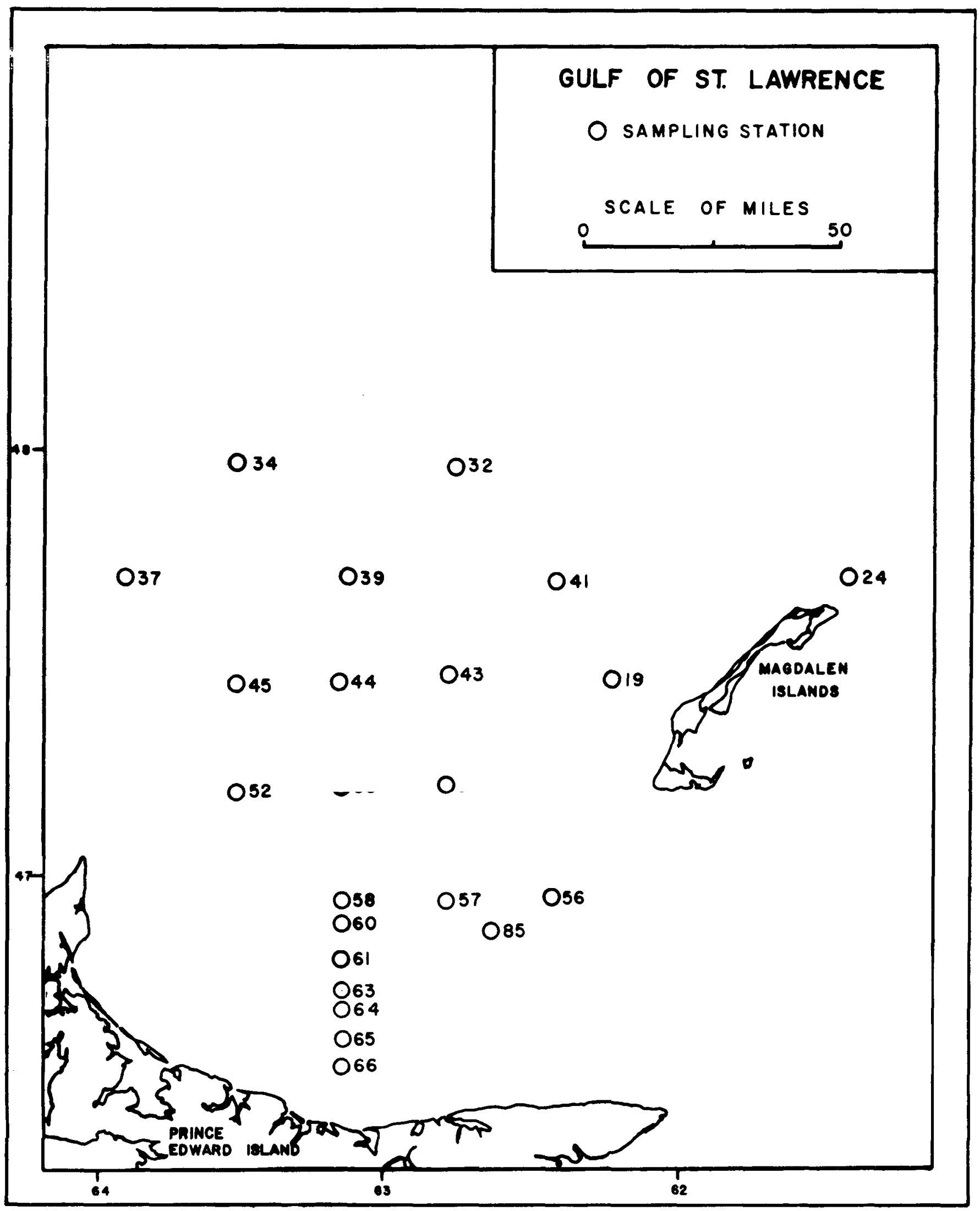

Figure 1 Location of sampling stations in Magdalen Shallows. 
TABLE I. Relative percentages of Foraminifera. Actual number of species in parentheses if less than one test per 10 grams of sample.

\begin{tabular}{|c|c|c|c|c|c|c|c|c|c|c|c|c|c|c|c|c|c|c|c|c|c|c|}
\hline $\begin{array}{ll}\text { Station Number } & 24 \\
\text { Depth in Metres } & 13 \\
\text { Tests per grm of Sample } & - \\
\text { Total Foraminifera } & - \\
\end{array}$ & $\begin{array}{r}19 \\
37 \\
1 \\
28 \\
28\end{array}$ & $\begin{array}{r}66 \\
37 \\
35 \\
1358 \\
\end{array}$ & $\begin{array}{r}65 \\
40 \\
18 \\
1178 \\
\end{array}$ & $\begin{array}{r}64 \\
42 \\
22 \\
1315 \\
\end{array}$ & $\begin{array}{r}63 \\
46 \\
28 \\
2321 \\
\end{array}$ & $\begin{array}{r}43 \\
51 \\
1 \\
58 \\
\end{array}$ & $\begin{array}{r}52 \\
55 \\
63 \\
2308 \\
\end{array}$ & $\begin{array}{r}41 \\
55 \\
7 \\
436 \\
\end{array}$ & $\begin{array}{r}61 \\
55 \\
15 \\
965 \\
\end{array}$ & $\begin{array}{r}54 \\
58 \\
20 \\
1001 \\
\end{array}$ & $\begin{array}{r}60 \\
60 \\
25 \\
896 \\
\end{array}$ & $\begin{array}{r}58 \\
60 \\
31 \\
1334 \\
\end{array}$ & $\begin{array}{r}53 \\
60 \\
11 \\
613 \\
\end{array}$ & $\begin{array}{r}44 \\
60 \\
19 \\
316 \\
\end{array}$ & $\begin{array}{r}85 \\
60 \\
19 \\
410 \\
\end{array}$ & $\begin{array}{r}39 \\
60 \\
16 \\
486 \\
\end{array}$ & $\begin{array}{r}37 \\
60 \\
13 \\
576 \\
\end{array}$ & $\begin{array}{r}34 \\
64 \\
35 \\
1223 \\
\end{array}$ & $\begin{array}{r}56 \\
64 \\
50 \\
906 \\
\end{array}$ & $\begin{array}{r}57 \\
64 \\
81 \\
1936 \\
\end{array}$ & $\begin{array}{r}45 \\
68 \\
13 \\
200 \\
200 \\
\end{array}$ & $\begin{array}{r}32 \\
77 \\
38 \\
810 \\
\end{array}$ \\
\hline $\begin{array}{l}\text { Ader cotryma qlomeratum } \\
\text { Ammotium cassis } \\
\text { Angulogerina angulosa } \\
\text { Asterellina qulchella } \\
\text { Astrononion gallowavi }\end{array}$ & & & & $\begin{array}{l}\text { (1) } \\
\text { (1) }\end{array}$ & (1) & (1) & $\begin{array}{l}\text { (4) } \\
\text { (3) } \\
\text { (5) }\end{array}$ & $\begin{array}{l}\text { (3) } \\
\text { (1) } \\
\text { (1) }\end{array}$ & (5) & & $\begin{array}{l}(2) \\
(2) \\
1.1\end{array}$ & $\begin{array}{l}\text { (1) } \\
(2)\end{array}$ & 2.1 & (1) & (2) & (6) & $\begin{array}{l}9.0 \\
\text { (i) } \\
1.2\end{array}$ & $\begin{array}{l}2.5 \\
(3) \\
0.7 \\
\end{array}$ & $\begin{array}{l}1.0 \\
8.8\end{array}$ & $\begin{array}{l}0.3 \\
0.2 \\
11) \\
3.8\end{array}$ & 2.8 & 0.8 \\
\hline 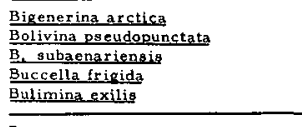 & & 5.2 & 14.4 & 20.2 & $\begin{array}{l}4.1 \\
(4) \\
(1) \\
0.4\end{array}$ & & 25.6 & 6.9 & 4.6 & 28,2 & 0.9 & 25.1 & 5.6 & 10.8 & 5.4 & 6.0 & 3.8 & $\begin{array}{l}10.5 \\
13) \\
3.3\end{array}$ & 5.1 & 1.9 & 6.2 & 16.7 \\
\hline 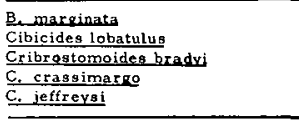 & & & & & $\begin{array}{l}0.5 \\
\text { (1) }\end{array}$ & (3) & 0.4 & $\begin{array}{l}\text { (1) } \\
\text { (1) }\end{array}$ & & & 4.3 & (3) & (1) & 1.1 & (2) & (6) & $\begin{array}{l}0.2 \\
(3) \\
(1) \\
2.8 \\
(1) \\
\end{array}$ & $\begin{array}{l}0.6 \\
6.9\end{array}$ & R. 4 & $\begin{array}{l}(2) \\
2.4 \\
(2) \\
\end{array}$ & (1) & (2) \\
\hline $\begin{array}{l}\text { C. subglobogum } \\
\text { Eggerella advena } \\
\text { Elphidium bartletti } \\
\text { E. incertum } \\
\text { E.subarcticurn } \\
\end{array}$ & 96.4 & $\begin{array}{r}89.6 \\
0.5 \\
0.4\end{array}$ & 70.8 & $\begin{array}{l}58.5 \\
\text { (4) }\end{array}$ & 73.0 & 77.6 & 8.9 & $\begin{array}{l}76.7 \\
(22)\end{array}$ & $\begin{array}{l}63.0 \\
1.4\end{array}$ & 43.6 & $\begin{array}{l}13.5 \\
12 . \\
26.6\end{array}$ & $\begin{array}{c}17.9 \\
(4) \\
6.8\end{array}$ & $\begin{array}{r}(1) \\
24.1 \\
4.1\end{array}$ & $\begin{array}{r}48.8 \\
2.5\end{array}$ & $\begin{array}{l}29.3 \\
(1)^{3} \\
15.3\end{array}$ & $\begin{array}{r}11.4 \\
43.9\end{array}$ & $\begin{array}{r}2.1 \\
1.3 \\
3.4 \\
121 \\
\end{array}$ & $\begin{array}{l}1.6 \\
3.2 \\
0.6 \\
\end{array}$ & $\begin{array}{r}16.4 \\
1.9 \\
21.2 \\
1.2 \\
1.3 \\
\end{array}$ & $\begin{array}{l}0.2 \\
18.3 \\
0.6 \\
7.9\end{array}$ & (1) & 25,9 \\
\hline $\begin{array}{l}\text { Globigerina sp. } \\
\text { Glomospira gordialia } \\
\text { Hippocrepina indivisa } \\
\text { Hyperammina sion. } \\
\text { Hylandiella ialandica } \\
\end{array}$ & & & (1) & (1) & (2) & & $\begin{array}{l}0.99 \\
\text { (i) }\end{array}$ & (3) & & & 1.2 & 0.7 & 3.9 & $\begin{array}{l}1.1 \\
\text { (1) } \\
\end{array}$ & $\begin{array}{l}\text { (1) } \\
3.0 \\
\end{array}$ & 2.9 & $\begin{array}{l}\text { (3) } \\
\text { (1) } \\
\text { (3) }\end{array}$ & $\begin{array}{l}0.5 \\
6.5 \\
\end{array}$ & 7.3 & $\begin{array}{l}0.7 \\
4.4 \\
\end{array}$ & & (2) \\
\hline $\begin{array}{l}\text { I. norcrosgl } \\
\text { Leretis } \\
\text { Lagena mollis } \\
\text { Miliammina fusca } \\
\text { Nonionella auricula } \\
\end{array}$ & & & & & (1) & & (1) & (2) & (1) & 1. 5 & $\begin{array}{l}2.7 \\
2.5 \\
\end{array}$ & $\begin{array}{l}0.5 \\
(2) \\
\end{array}$ & $\begin{array}{l}1.1 \\
2.1 \\
2.7 \\
\end{array}$ & $\begin{array}{l}\text { (1) } \\
1.7 \\
\end{array}$ & $\begin{array}{c}(1) \\
(2) \\
2.4 \\
\end{array}$ & 3.2 & $\begin{array}{l}19.2 \\
(1) \\
1.1 \\
(3) \\
\end{array}$ & $\begin{array}{l}0.7 \\
5.0 \\
1.0 \\
\end{array}$ & $\begin{array}{l}4.3 \\
0.9 \\
\end{array}$ & $\begin{array}{l}6.3 \\
0.7 \\
2.5 \\
\end{array}$ & $\begin{array}{c}11) \\
2.8 \\
\end{array}$ & $\begin{array}{l}10.3 \\
\text { (3) }\end{array}$ \\
\hline 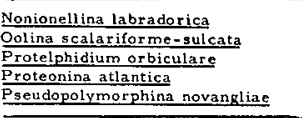 & & $\begin{array}{l}\text { (1) } \\
\text { (1) }\end{array}$ & (1) & (4) & 0.5 & & (1) & $\begin{array}{l}2.1 \\
(2) \\
(1) \\
\end{array}$ & (5) & 0.5 & 0.5 & $\begin{array}{l}\text { (1) } \\
\text { (1) } \\
\text { (3) }\end{array}$ & $\begin{array}{l}2.9 \\
\text { (1) }\end{array}$ & $\begin{array}{l}0.6 \\
0.6 \\
0.6\end{array}$ & 5.1 & $\begin{array}{l}2.3 \\
\text { (1) } \\
\text { (1) }\end{array}$ & $\begin{array}{l}\text { (2) } \\
\text { (4) }\end{array}$ & $\begin{array}{l}0.6 \\
0.6\end{array}$ & $\begin{array}{l}1.6 \\
\text { (11) }\end{array}$ & $\begin{array}{l}\text { (1) } \\
0.4 \\
0.2\end{array}$ & 1.8 & $\begin{array}{l}0.5 \\
\text { (1) } \\
\text { (1) }\end{array}$ \\
\hline $\begin{array}{l}\text { Recurvoides cutbinatua } \\
\text { Reophax curtug } \\
\text { R. scotti } \\
\text { Saccammina sphaerica } \\
\text { Spiroplectammina biformis }\end{array}$ & & (3) & $\begin{array}{l}6.2 \\
6.2 \\
\end{array}$ & $\begin{array}{l}(4) \\
13.0 \\
\end{array}$ & $\begin{array}{l}\text { (1) } \\
\text { (1) } \\
15.0 \\
\end{array}$ & B. 6 & $\begin{array}{r}2.0 \\
\text { (ii) } \\
38.6 \\
\end{array}$ & $\begin{array}{l}\text { (2) } \\
\text { (1) } \\
\text { (3) }\end{array}$ & 17.7 & $\begin{array}{r}11 \\
(1) \\
1.6 \\
19.7 \\
\end{array}$ & $\begin{array}{r}10.3 \\
0.5 \\
41.6 \\
\end{array}$ & $\begin{array}{l}1.1 \\
(1) \\
27.8 \\
\end{array}$ & $\begin{array}{l}3.0 \\
13)^{2} \\
31.2 \\
\end{array}$ & $\begin{array}{r}3.3 \\
2.8 \\
12.7 \\
\end{array}$ & $\begin{array}{l}1.8 \\
(11) \\
20.7 \\
\end{array}$ & $\begin{array}{l}2.7 \\
0.7 \\
14.6 \\
\end{array}$ & $\begin{array}{l}.4 \\
2.1 \\
36.3 \\
\end{array}$ & $\begin{array}{l}.4 \\
1.3 \\
34.1 \\
\end{array}$ & $\begin{array}{l}1.5 \\
0.8\end{array}$ & $\begin{array}{c}5.5 \\
3.9 \\
(1) \\
10.5\end{array}$ & $\begin{array}{l}6.7 \\
\text { (1) } \\
61.5 \\
\end{array}$ & $\begin{array}{l}2.7 \\
2.8 \\
(1) \\
24.3 \\
\end{array}$ \\
\hline 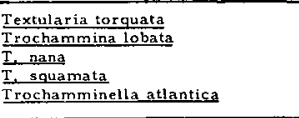 & (1) & $\begin{array}{l}1.5 \\
\text { (1) }\end{array}$ & 1.1 & 5.8 & 5.1 & & $\begin{array}{l}21.1 \\
1.33 \\
(3)\end{array}$ & $\begin{array}{l}4.1 \\
1.7 \\
\text { (1) } \\
(2) \\
\end{array}$ & $\begin{array}{l}6.8 \\
1.0 \\
\text { (1) } \\
\end{array}$ & $\begin{array}{l}3.4 \\
0.5\end{array}$ & $\begin{array}{l}7.3 \\
4.1\end{array}$ & $\begin{array}{l}1.9 \\
2.2 \\
14 \\
121 \\
\end{array}$ & $\begin{array}{l}9.6 \\
\text { (3) } \\
\text { (1) }\end{array}$ & $\begin{array}{l}1.9 \\
3.9\end{array}$ & $\begin{array}{l}8.1 \\
0.9\end{array}$ & $\begin{array}{l}9.1 \\
\text { (2) }\end{array}$ & $\begin{array}{l}13.9 \\
1.3\end{array}$ & $\begin{array}{l}11.9 \\
\text { (1) } \\
\text { (1) }\end{array}$ & $\begin{array}{l}9.6 \\
\text { (1) } \\
\text { (1) } \\
\end{array}$ & $\begin{array}{l}11.5 \\
1.3 \\
\text { (2) } \\
\end{array}$ & 14.5 & 12.4 \\
\hline
\end{tabular}




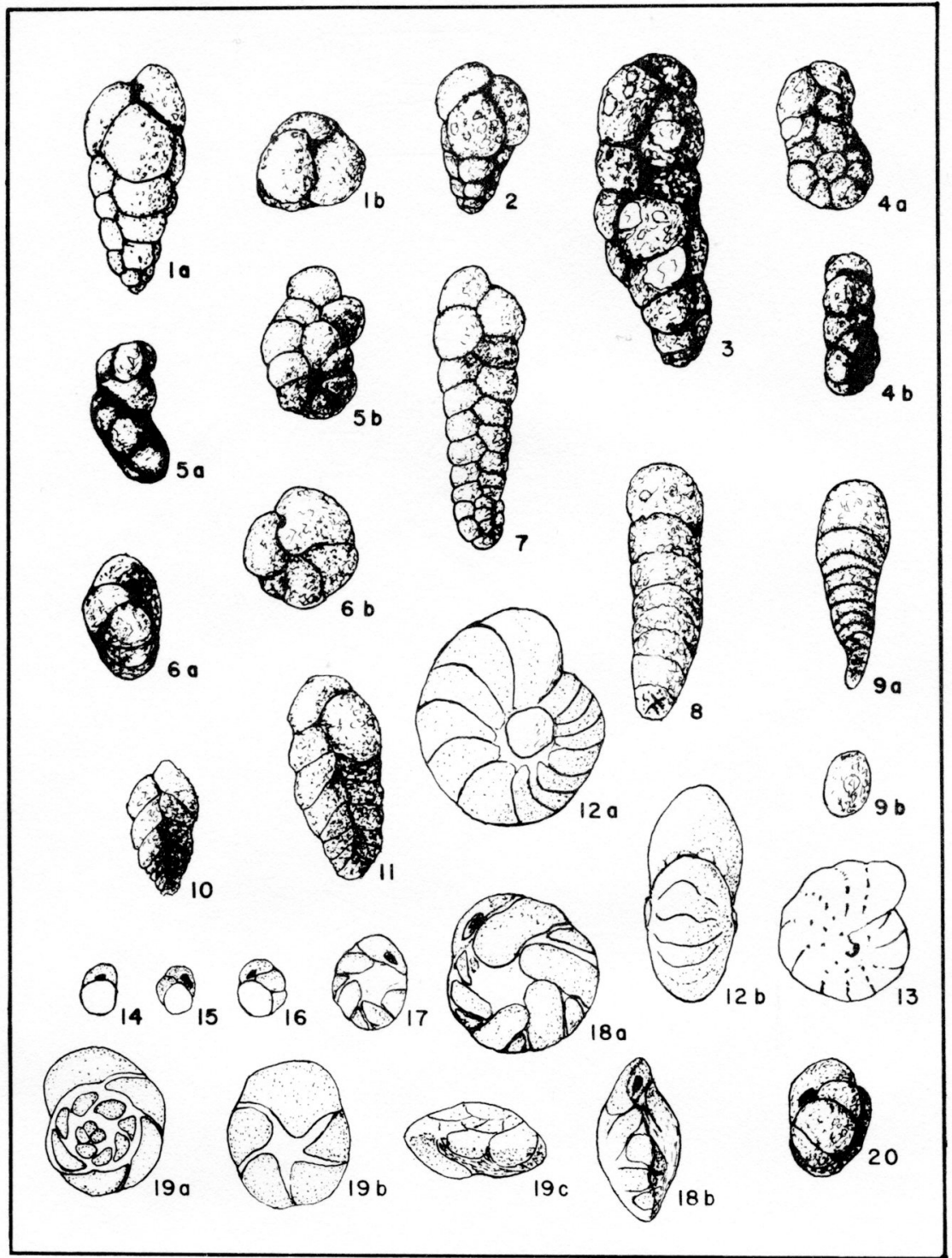

Explanation of Plate

Figures la-b,2,3, Eggerella adveno (Cushman). Figs. 1a,2,3, side view, fig. Ib apertural view. Figs. la-b fram station 61 , fig. 2 from 85 and fig. 3 from station 19. All figures $\times 125$.

Figures 4a-b,5a-b,6a-b,7, Spiroplectammina biformis (Porker and Jones). Figs. 4a,5b and 6b side view, figs.4b, 50 and $6 a$ edge view. Figs.4a-b from station 58 , figs.5a-b,6a-b and 7 from station 44 . all figures $X 125$.

Figures $8,9 a-b$, Bigenerina orctica (Brady), figs. 8 and $9 a$ side view, fig. apertural view. Fig. 8 from station 54 and figs. $9 a-b$ from station 52 .

Figures 10, 11, Textularia torquata(F. Parker), side view. Fig. 10 from station 61 and fig. 11 from station 58. All figures $\times 125$.

Figures 12a-b, Elphidium incertum (Williamson) Fig. 12a side view, fig. $12 b$ edge view. Specimen from 5 tation 56. Magnification X 62.5 .

Figures 14-18a-b, Islandiella teretis (Tappon), Figs. 14-17 juvenile species, fig. 18a side view of adult,, fig. 18b edge view. Specimens from station 37. Magnification $X$ 62.5.

Figures 19a,b,c, Buccella frigida (Cushman). Fig. 19a dorsal view, 19a ventral view and 19c edge view. Specimen from station 60. Magnification X 125 .

Figure 20, Recurvoides furbinatus (Brady), apertural view. Specimen from station 60. Magnification $X 62.5$. 
detail with a discussion of their distribution in the Magdalen Shallows, the Arctic and the North Atlantic.

Eggerella advena (Cushman) (Plate I, figs. la-b, 2,3) is the most abundant species. It is present in every sample, with the average relative abundance 34 per cent, highest 96.4 and lowest 0.5 per cent. The species is an important member of the foraminiferal population in the Arctic and Subarctic waters. Cushman (1922) and Leslie (1963) recorded E. advena in nearshore samples in Hudson Bay, Loeblich and Tappan (1953) from localities at Point Barrow, Aleutian Islands, Mellville Peninsula, Frobisher Bay and off Northern Greenland. Bartlett (1963) reports $E$. advena from the Scotian Shelf, where it is a typical inshore species. Vilks (1967) found E. advena in Bras d'Or Lakes as the most abundant species, but not in the Frozen Arctic, i. e., in Prince Gustaf Adolf Sea, Hecla and Griper Bay and Hazen Strait.

Sprioplectammina biformis (Parker and Jones), (Plate I, figs, 4a-b, 5a-b, 6a-b, 7) is present in 21 stations with the average relative abundance 13.5 per cent and highest 36.3 per cent. The species varies morphologically to a greater extent than in the Arctic. Specimens vary from a high number of biserial chambers, (Plate I, fig. 7) to only two or three per test (Plate I, figs. $5 a-b)$. Figure 6 shows a specimen with a biserial portion missing and the last chamber added in a different plane. Most commonly the planes of symmetry of the planispiral and the biserial parts make an angle that may be as high as 90 degrees. The typical $\underline{\mathrm{S}}$. biformis is shown in figures $4 a-b$.

Spiroplectammina biformis is a very common inshore species of the Arctic and North Atlantic Oceans. The species is found along the Siberian Coast (Stschedrina, 1958), Point Barrow, Frobisher Bay, off Greenland, Ungava Bay and Hudson Bay. It is also found on the Scotian Shelf, Gulf of Maine and the inshore waters of the East North Atlantic (Hoglund, 1947). S. biformis is easily the most abundant inshore species of Prince Gustaf Adolf Sea, Hazen Strait and Hecla and Griper Bay, N. W. T.

Textularia torquata F. Parker, (Plate I, figs. 10, 1l) occurs at 20 localities of the 23 investigated. The average relative per cent is 8.7 with 18.9 per cent maximum. T. torquata is absent in the coarse sediments extending to the west of the Magdalen Islands. The species occurs off Point Barrow, in Frobisher Bay, Ungava Bay, Foxe Channel, Labrador Sea, Baffin Bay, Kane Basin, Kennedy Channel, Prince Gustaf Adolf Sea, Hazen Strait and Hecla and Griper Bay.

Bigenerina arctica (Brady), (Plate I, figs, 8, 9a-b) was found in 19 stations and is more abundant in coarse sediments. The majority of the species are minute with a rough surface texture, consisting of relatively large sand grains. The specimens are examined in glycerol. This permits a view of the early biserial stage of the test. B. arctica is reported from Baffin Bay, Kane Basin, Lancaster Sound, Melville Sound, Point Bärrow, Frobisher Bay, Ungava Bay and Hudson Bay. It is also present in the shallow waters of the Scotian Shelf and Bras d'Or Lakes, but is absent from the Prince Gustaf Adolf Sea, Hazen Strait and Hecla and Griper Bay.

Elphidium incertum (Williamson) (Plate I, figs. 12a-b, 13) is a common species in the central region of the Magdalen Shallows and occurs at 13 stations. The maximum relative abundance is 26.6 per cent. It is a common shallow water species along the coast of Nova Scotia, is present at Point Barrow, but is rare in the shallow waters of Hecla and Griper Bay and Hazen Strait and absent from the East Bay sediments of Mackenzie King Island.

Islandiella teretis (Tappan) (Plate I, figs, 14-18a-b) occurs at 14 stations, mainly in the central and western parts of the area. The figured specimen demonstrate the different growth stages of the species. Figure 14 shows a juvenile, consisting of a large, bulbose proloculus to which one chamber is added. Figure 15 shows a specimen with two chambers added, figure 16 with three added. Figure 18 shows an adult where the initial proloculus is still visible as a clear area in the central part of the test. The sketches were made with the specimens immersed in glycerol.

T. teretis is abundant at Point Barrow, Frobisher Bay, Baffin Bay, Ungava Bay, Foxe Channel and on the Scotian Shelf. The species is rare above the 200 metre isobath in Prince Gustaf Adolf Sea, Hazen Strait and Hecla and Griper Bay but abundant in deeper waters of these areas.

Buccella frigida (Cushman), (Plate I, figs. 19a, b, c) occurs at 20 stations in moderate 
abundances with a slight preference to fine sediments. Identification of $B$. frigida was difficult owing to the wide range of morphological features of the species. The figured specimen is typical of the species found on the Magdalen Shallows. It shows a biconvex test with equal convexities on both dorsal and ventral sides. Besides these, there are a large number of variants with extremely convex dorsal sides. B. frigida occurs at Point Barrow, in Hudson Bay, Foxe Channel, Prince Gustaf Adolf Sea, Hazen Strait, Hecla and Griper Bay and Scotian Shelf.

\section{Summary and Conclusions}

The foraminiferal population of the Magdalen Shallows is relatively sparse and is dominated by arenaceous species. Eggerella advena, Spiroplectammina biformis and Bigenerina arctica are the three most abundant forms and constitute 60 per cent of the total population. From the calcareous group Elphidium incertum, Buccella frigida and Islandiella teretis occur in greatest numbers. The distribution of species have the following trends: 1) More species per sample occur at the deeper offshore stations; 2) As a rule, finer sediments contain more fauna. An exception is Eggerella advena, which appears to be more abundant in coarser sediments; 3) Geographically, the fauna is comparable to Arctic forms.

The Arctic character of the Magdalen fauna was expected, considering the low temperatures of the water. However, it is interesting to note that Eggerella advena and Bigenerina arctica, which are very abundant both in the Arctic and the Magdalen Shallows, are not found in the Frozen Arctic, that is, in areas that are normally covered with at least eighttenths of ice during the summer season. The exclusion of these two species from the Frozen Arctic may be related to a lack of the turbulent surface zone in the ice-covered areas.

\section{$\underline{\text { References cited }}$}

BARTLETT, G. A. , 1963, A preliminary study of Foraminifera distribution on the Atlantic Continental Shelf Southeastern Nova Scotia: Geol. Surv. Canada, Paper 64-5, pp. 1-22.

1965, Preliminary notes on Recent species of Elphididae in shallow waters of the Atlantic Provinces of Canada: Report BIO 65-13, Bedford Institute, Dartmouth, Canada, pp. 1-27, pl. 1 (Unpublished Manuscript).

1966, Distribution and abundance of Foraminifera and Thecamoebina in Miramichi River and Bay: Report BIO 66-2, Bedford Institute, Dartmouth, Canada, pp. 1107, pls. 1-2, (Unpublished Manuscript).

CUSHMAN, J.A., 1922, Results of the Hudson Bay expedition, 1920. I. The Foraminifera: Contr. Canadian Biol. , no. 9 (1921), pp. 135-147.

1948, Arctic Foraminifera: Cushman Lab. Foram. Res. Spec, Publ. 23, pp. 1-79, pls. $1-8$.

DAWSON, J. W. , 1870, Foraminifera from Gulf and River St. Lawrence; Canadian Naturalist, 2nd. Series, vol. 5, pp. 172-180.

HOGLUND, H. , 1947, F oraminifera in the Gullmar Fjord and the Skagerak; Zool. Bidrag Uppsala, vol. 26, pp. 1-328, pls. 1-32.

LAUZIER, L. M. , 1957, Bottom temperatures of the Magdalen Shallows: Bull. Fish. Res. Bd. Canada, No. 111, pp. 269-285.

LESLIE, R. J., 1963, Foraminiferal study of the cross-section of Hudson Bay, Canada: Geol. Surv. Canada, Paper 63-16, pp. 1-28, tfs. 1-5.

LOEBLICH, A. R., Jr., and TAPPAN, H., 1953, Studies of Arctic Foraminifera: Smithsonian Misc. Coll., vol. 121, no. 7, pp. 1-150, pls. 1-24.

PARKER, F. L., 1952a, Foraminifera species off Portsmouth, New Hampshire, Bull. Harvard Mus. Comp. Zool., vol. 106, no. 9, pp. 391-423, pls. 1-6. 
PARKER, F. L., 1952b, Foraminiferal distribution in the Long Island Sound - Buzzards Bay Area: Bull. Mus. Comp. Zool., vol. 106, no. 10, pp. 425-473, pls. 1-5.

PHLEGER, F.B., 1952, Foraminifera distribution of some sediment samples from the Canadian and Greenland Arctic: Contr. Cushman Found. Foram. Res., vol. 3, pt. 2, pp. $80-89$.

SCHAFER, C. T., 1967, Factors influencing the numerical accuracy of benthonic Foraminifera population counts from bottom sediment samples, Gulf of St. Lawrence: Maritime Sediments, vol. 3 , nos. 2 \& 3 , p. 71.

SPROULE, H.F., 1961, A regional study of the distribution of benthonic Foraminifera in the Gulf of St. Lawrence, Canada, Unpublished BSc. thesis, Carleton University, Ottawa.

STSCHEDRINA, Z. G., 1958, The dependence of the distribution of Foraminifera in the seas of the U.S.S. R. on the environmental factors; 15th Internat. Congr. Zool., sec. 3, Paper 30, pp. 1-3.

VILKS, G., 1964, Foraminiferal study of East Bay, Mackenzie King Island, District of Franklin Polar Continental Shelf Project: Geol. Surv. Canada, Paper 64-53, pp. 1-26.

1967, Quantitative analysis of Foraminifera in Bras d'Or Lakes: BIO Rept. 67-1, Bedford Institute, pp. 84, (Unpublished Manuscript).

\section{Foraminifera Reference List}

(Starred references are original to the species)

Adercotryma glomeratum (Brady) - *Lituola glomerata Brady, 1878, Ann. Mag. Nat. Hist., ser. 5, vol. 1, p. 433, pl. 20, figs. la-c.

Ammotium cassis (Parker) - Loeblich and Tappan, 1953, Smithsonian Misc. Coll., vol. 121, no. 7, p. 33, pl. 2, figs, $12-18$.

Angulogerina angulos a (Williamson) - *Uvigerina angulosa Williamson, 1858, Roy. Soc., p. 67, p1. 5., fig. 140 .

Asterellina pulchella (Parker) - *Pninaella (?) pulchella Parker, 1952, Bull. Mus. Comp. Zool., vol. 106, no. 9, p. 420, pl. 6, figs. $18 \mathrm{a}, \mathrm{b}, 19,20$.

Astrononion gallowayi Loeblich and Tappan, 1953, *Smithsonian Misc. Coll., vol. 121, no. 7, p. 90 , pl. 17, figs. 4-7.

Bigenerina arctica (Brady) - Cushman Lab. Foram. Res, Spec. Publ, 23, p. 31, pl. 3, figs. 9-11.

Bolivina pseudopunctata Hoglund, 1947, *Zool. Bidrag Uppsala, vol. 26, p. 273, pl. 24, figs. 5a-b.

Bolivina subaenariensis Cushman - Parker, 1952, Bull. Mus. Comp. Zool., vol. 106, no. 3, p. 414, pl. 5, fig. 22 .

Buccella frigida (Cushman) - Anderson, 1952, Journ. Washington Acad. Sci., vol. 42, no. 5, p. 144, figs. 4a-c, 5, 6a-c.

Bulimina exilis Brady - *Bulimina elegans d'Orbigny var. exilis Brady, 1884, Rept. Voy. "Challenger", vol. 9, (Zoology), p. 399, pl. 50, figs. 5-6.

Bulimina marginata d'Orbigny - Parker, 1952, Bull. Mus. Comp. Zool., vol. 106, no. 9, p. 415, .pl. 5, fig. 26.

Cibicides lobatulus Walker and Jacob - Cushman, 1948, Cushman Lab. Foram. Res. Spec. Publ. 23, p. 78, pl. 8, figs. $14 a-c$.

Cribrostomoides bradyi (Robertson) - Haplophrgmoides bradyi (Robertson) Phleger and Parker, 1951, G.S. A. Memoir 16, Part II, pl. 1, fig, 10.

Cribrostomoides crassimargo (Norman) - Alveolophragmium crassimargo (Norman) Loeblich and Tappan, 1953, Smithsonian Misc. Coll., vol. 121, no. 7, p. 29, figs. 1-3.

Cribrostomoides jeffreysi (Williamson) - Alveolophragmium jeffreysi (Williamson) - Loeblich and Tappan, 1953, Smithsonian Misc. Coll., vol. 121, no. 7, p. 31, p1. 3, figs. 4-7.

Cribrostomoides subglobosum (G. O. Sars) - Labrospira subglobosa (G. O. Sars) - Cushman, 1948, Cushman Lab. Foram. Res. Spec. Publ. 23, p. 28, pl. 3, figs. 3a-b.

Eggerella advena (Cushman) - Loeblich and Tappan, 1953, Smithsonian Misc. Coll., vol. 121, no. 7, p. 36, pl. 3, figs. 8-10.

Elphidium bartletti Cushman, 1933, *Smithsonian Misc. Coll., vol. 89, no. 9, p. 4, pl. 1, fig. 9. 
Elphidium incertum (Williamson) - Phleger, 1952, Contr. Cushman Found. Foram. Res., vol. 3, pt. 2, p. 83, pl. 14, fig. 7 .

Elphidium subarcticum Cushman - Parker, 1952, Bull. Mus. Comp. Zool., vol. 106, no. 9, pl. 5, fig. 9.

Glomospira gordialis (Jones and Parker) - Cushman, 1948, Cushman Lab. Foram. Res., Spec. Publ. 23, p. 25, p1. 2, figs. 9, 10.

Hippocrepina indivisa Parker - Cushman, 1948, Cushman Lab. Foram. Res., Spec. Publ. 23, p. 21, pl. 2, figs. 4, 5.

Islandiella islandica (Norvang) - Cassidulina islandica Norvang - Loeblich and Tappan, 1953, Smithsonian Misc. Coll., vol. 121, no. 7, p. 118, pl. 24, fig. 1 .

Islandiella norcrossi (Cushman) - *Cassidulina norcrossi Cushman 1933, Smithsonian Misc. Coll. , vol. 89, no. 9, p. 7, pl. 2, figs. 7a-c.

Islandiella teretis (Tappan) - *Cassidulina teretis Tappan, 1951, Contr. Cushman Found. Foram. Res., vol. 2, pt. 1, p. 7, pl. 1, figs. 30a-c.

Lagena mollis Cushman - Loeblich and Tappan, 1953, Smithsonian Misc. Coll., vol. 121, no. 7, p. 63, pl. 11, figs. 25-27.

Miliammina fusca (Brady) - Parker, 1952, Mus. Comp. Zool. Bull, vol, 106, no, 10, pl. 2, figs. $6 \mathrm{a}-\mathrm{b}$.

Nonionella auricula Heron-Allen and Earland - Loeblich and Tappan, 1953, Smithsonian Misc. Coll., vol. 121, no. 7, p. 92, pl. 16, figs. 6-7.

Nonionellina labradorica (Dawson) - Nonion labradoricum (Dawson) - Loeblich and Tappan, 1953, Smithsonian Misc. Coll., vol. 121, no. 7, p. 86, pl. 17, figs. 1, 2.

Oolina scalariforme-sulcata (Wiesner) - Loeblich and Tappan, 1953, Smithsonian Misc. Coll., vol. 121, no. 7, p. 72 , pl. 13, fig. 7 .

Protelphidium orbiculare (Brady) - Todd and Low, 1961, Contr. Cushman Found. Foram. Res., vol. 12 , pt. 1, p. 20, pl. 2, fig. 11 .

Proteonina atlantica Cushman - Parker, 1952, Bull. Mus. Comp. Zool., vol. 106, no. 10, p. 454, pl. 1, figs. 1,2 .

Pseudopolymorphina novangliae (Cushman) - *Polymorphina lactea (Walker and Jacob) var. novangliae Cushman, 1923, U.S. Nat, Mus. Bull., 104, pt. 4, p. 146, pl. 39, figs. 6-8.

Recurvoides turbinatus (Brady) - *Haplophragmium turbinatum Brady, 1884, Rep. Voy. Challenger, vol. 9, (Zoology), p. 313, figs. 9a-c.

Reophax curtus Cushman - Loeblich and Tappan, 1953, Smithsonian Misc. Coll., vol. 121, no. 7, p. 22, pl. 2, figs. 1-4.

Reophax scotti Chaster - Parker, 1952, Bull. Mus. Comp. Zool., vol. 106, no. 9, p. 397, fig. 1 .

Saccammina sphaerica M. Sars - Brady, 1884, Rep. Voy. Challenger, vol. 9, (Zoology), p1. 18, figs. $11,13,15$.

Spiroplectammina biformis (Parker and Jones) - Loeblich and Tappan, 1953, Smithsonian Misc. Coll., vol. 121, no. 7, p. 34, p1. 4, figs. 1-6.

Textularia torquata F. Parker, 1952, *Bull. Mus. Comp. Zool. vol. 106, no. 9, p. 403, pl. 3, figs. 9-11.

Trochammina lobata Cushman, 1944, *Cushman Lab. Foram. Res. Spec. Publ. 12, p. 18, pl. 2, fig. 10.

Trochammina nana (Brady) - *Haplophragmium nanum Brady, 1881, Ann., Mag. Nat. Hist., ser. 5 , no. 48, pl. 21 , figs. la-c.

Trochammina squamata Parker and Jones - Parker, 1952, Bull. Mus. Comp. Zool. vol, 106, no. 9 , p. 408 , pl. 4, figs. 11-16.

Trochamminella atlantica F. Parker, 1952 - *Bull. Mus. Comp. Zool., vol, 106, no. 9, p. 409, pl. 4, figs. $17 \mathrm{a}, \mathrm{b}, 18,19$. 